\title{
Pathways Between Engineering and Education Faculties: EfForts to Establish an EngINeEring EduCATION Graduate Program at THE UNIVERSITY OF MANITOBA
}

\author{
Sandra Ingram, Richard Hechter, Jillian Seniuk Cicek and Douglas Ruth \\ Faculty of Engineering, University of Manitoba, Winnipeg, MB, Canada R3T 5V6 \\ Sandra.Ingram@umanitoba.ca
}

\begin{abstract}
Engineering education is a recognized field of research and inquiry that draws on a number of established disciplines to enhance the practice and teaching of engineering. Within the last ten years, some universities in the U.S. and abroad have developed engineering education graduate programs with an emphasis on drawing from the education discipline in particular. These programs range in scope from those in which graduate students maintain a technical area of expertise alongside a focus on pedagogy to more interdisciplinary collaborations with education faculties. In Canada, such programs are still in development and the more recent movement towards outcomes-based assessment in engineering schools to satisfy changing accreditation requirements, has further mobilized an institutional interest in teaching and learning processes. This paper reports on the evolution of such a program, combining the expertise of both engineering and education faculties at the University of Manitoba to achieve this synergy.
\end{abstract}

Keywords: engineering education; graduate studies; pedagogy.

\section{INTRODUCTION}

Engineering and education faculties are seldom mentioned in the same sentence; the conventional understanding is that one school develops prospective engineers while the other prepares future teachers. Often overlooked is the common element that links these two fields: their attention to pedagogy - the teaching, learning and assessment processes in which both instructors and students invest considerable time and effort, shaping career outcomes. Engineering education in a formal capacity is a relatively new discipline, emerging within the last $15-20$ years and drawing from a number of other fields, including the social sciences, educational research, and the cognitive and learning sciences to create a unique synthesis with its own expanding scholarly base [1][2][3][4][5][6][7] [8][9][10][11][12].
Much of the thinking behind this enhanced view of scholarship can be attributed to Boyer [13], who argued that the intellectual rigor of scholarly activities should extend beyond conducting original research and publishing, and rather be connected to four inter-related activities: discovery, integration, application and teaching [5][14][15]. The scholarship of discovery is the act of creating new knowledge within a given discipline, while the scholarship of integration connects information between different disciplines and areas of knowledge. The scholarship of application builds on the prior two forms of scholarship to ask 'how can this knowledge be used?' For example, engineering course revisions can be informed by the findings from the research on cognitive psychology and learning theory, and similarly, K-12 teachers can be helped to understand how to best teach engineering and scientific concepts by familiarizing themselves with the research in engineering education. Finally, the scholarship of teaching puts the results of research into action, whereby teachers make active efforts to incorporate their new knowledge into their courses, thereby integrating teaching and scholarship [16]. For example, borrowing from the field of education, the 'pedagogies of engagement,' which have been shown to promote academic learning and integration and which encourages active learning, including cooperative, problem-based, project-based, case-based and service learning, have been incorporated by growing numbers of engineering faculty [17][18]. Boyer's four forms of scholarship are not seen as independent, but rather each overlaps the other and exerts influence on the other domains [19].

\section{ENGINEERING EDUCATION PROGRAMS - GLOBAL OVERVIEW}

Recognizing the need and benefits of focusing on the pedagogy of engineering, more formalized programs in engineering education have been recently established, such as Ph.D. graduate degree programs and university departments in several prestigious American universities [2][4][20]. In fact, there are about 20 centers involving Engineering Education research, most established within the last decade [3]. Such programs vary in structure and 
scope. They range from those open exclusively to engineering graduate students who, alongside their own technical area of expertise, take courses in areas such as principles of curriculum development and educational research methods, or they may take the form of crossdisciplinary approaches in which graduates from other disciplines have the ability to develop, implement, and assess engineering curricula at high school and university levels.

American institutions that offer graduate programs in engineering/STEM education include: Arizona State University, University of California - Berkeley, University of Cincinnati, Clemson University, University of Kentucky, Louisiana Tech University, University of Maryland, The College of New Jersey, Niagara University, North Carolina State University, Old Dominion University, The Ohio State University, Purdue University, University of Texas, Tufts University, Utah State University, Virginia Tech [21]. The obtainable degrees are diverse, with programs offered through Departments, Schools and Colleges of Education, as well as through Departments and Schools of Engineering and STEM Education. Additionally, there are a number of American institutions that provide engineering education-related certificate programs [21]. The article, "Engineering Education: Departments, Degrees and Directions," published in the International Journal of Engineering Education in 2010, details the formation of four American engineering education academic units: the School of Engineering Education at Purdue University, the Department of Engineering Education at Virginia Tech, the Department of Engineering and Technology Education at Utah State University, and the Department of Engineering and Science Education at Clemson University, exemplifying typical characteristics of the programs. The authors also discuss atypical and amalgam engineering education cultivation [22].

Along with the critical infrastructure of centers and departments now established predominantly in the U.S., there is also an increasingly enlarging global community of engineering education researchers [1][2][3][23] and established international institutions that offer engineering education research programs. Graduate programs in engineering/STEM education are found at Aalborg University in Denmark, Chalmers University of Technology, Linkoping University and Uppsala University in Sweden, Universiti Kebangsaan Malaysia and Universiti Teknologi Malaysia in Malaysia, and Universidad de las Americas, Puebla in Mexico [21]. As well, several international and American institutions house innovative engineering and interdisciplinary programs. (For a comprehensive list of engineering education programs and degrees awarded, see Appendices A-C, and the Engineering Education Community Resource wiki [21].) All of these engineering education initiatives, as well as the numerous journals, associations and conferences devoted exclusively to the intellectual growth of engineering education research are fundamental to the expansion of the discipline of engineering education.

\section{ENGINEERING EDUCATION PROGRAMS AND INITIATIVES IN CANADA}

To date, there is one degree program in Canada that offers a formal certificate in engineering education, although arguably studies in engineering education are not novel. The University of Toronto, through the Faculty of Applied Science and Engineering, has a Collaborative Program in Engineering Education. It is described as an interdisciplinary opportunity designed for students in engineering or education who are interested in taking courses and conducting research in engineering education. Students receive the notation "Completed Collaborative Program in Engineering Education" on their transcript when they successfully complete requirements of both their home department and the program [24].

While developments have been slower to take hold in Canada, there have nonetheless been significant initiatives within the last few years. In 2009, the Canadian Engineering Accreditation Board (CEAB) began an outcomes-based approach for engineering curriculum development and assessment [25][26][27]. Similar to events that took place in the U.S. in the 1990s due to their changing accreditation requirements through ABET [28][29][30], Canadian engineering schools are now seeking and embracing educational expertise in order to engage in rigorous, scholarly, and scientifically driven research in engineering education [1][3][8].

At the crux of the movement, is the formation of the Canadian Engineering Education Association (CEEA), a relatively new organization whose mission is to "enhance the competence and relevance of graduates from Canadian engineering schools through continuous improvement in engineering education and design education.' Additional Canadian engineering education initiatives include the DuPont Canada Chair of Engineering Education Research and Development that is held by a faculty member at Queen's University [32], and the STEM Teaching and Learning Community that has recently been established at the University of Calgary between the Werklund School of Education, the Faculty of Science, and the Schulich School of Engineering [33], and now the Centre for Professional Practice and Engineering Education at the University of Manitoba. CEEA, changing accreditation requirements, global influences, and the impact of the learning sciences on engineering education [31] have thus fueled a growing interest among Canadian engineering academics and practitioners in the field of engineering education. 


\section{ENGINEERING EDUCATION AT THE UNIVERSITY OF MANITOBA - HISTORY}

Interest in engineering education at the University of Manitoba has grown steadily over the last 15 years. Initiated by individual professors who wished to explore innovative classroom methods or motivated by the need to document such activities as our Engineering Access Program and the Internationally Educated Engineering Qualifications Program, engineering education has gradually become a component of our scholarship.

This focus has been sharpened by two developments. The first development was that Dr. Ron Britton, the faculty's former NSERC Design Chair, was a major proponent in the formation of the Canadian Engineering Education Association (CEEA). Strong support for this organization has come from three successive Deans of Engineering at the University of Manitoba. This support extends to housing the Secretariat for CEEA in Manitoba.

The second development was the strong encouragement provided by the visiting team in 2011 for the third term of the NSERC Design Chair at the University of Manitoba, where Dr. Douglas Ruth is the current chair holder. Two of the visiting team members were from engineering education programs in the United States. A recommendation in their review was that a formal recognition of engineering education should be a necessary component of the program. The new chair program has wholly incorporated this suggestion. As one demonstration of this, the Chair has committed to provide support for any researcher at the University of Manitoba who is presenting research findings at the annual CEEA conference or any other engineering education or educational forum. This support has grown to include annual provision for over 20 individuals conducting engineering education research from the University of Manitoba.

Over the last 15 years, the Faculty of Engineering has built a strong engineering education group around the NSERC Design Chair. First called the "Design Group," this organization has now been formally constituted as the "Centre for Engineering Professional Practice and Engineering Education" (CE2P2E). The University Senate confirmed its status as an 'Academic Centre,' the first such Centre at the University of Manitoba, in May 2014. The Centre highlights our commitment to support engineering education as a field of rigorous, scientific and creative scholarship.

\section{WHY AN ENGINEERING EDUCATION GRADUATE DEGREE?}

In the past, there have been a number of graduate students completing degrees at the University of
Manitoba who could claim that they were doing "engineering education" research. These students came from two distinct academic backgrounds, and had to be treated very differently from an administrative perspective. The first group was those with undergraduate degrees in Engineering. These degrees allowed them to register for graduate degrees in the Faculty of Engineering. With the cooperation of particular Engineering Departments (most notably the Department of Biosystems Engineering), these students were allowed to pursue engineering education research for their graduate programs. Generally, these students had members of the Faculty of Education on their committees, but committee members from Education functioned under Faculty of Engineering rules. The second group were students who did not have a first degree in Engineering. These students pursued what are termed "Interdisciplinary" degrees that function under very different rules from those in the Faculty of Engineering. In particular, it is required that students embarking on an Interdisciplinary degree take at least one course from the home departments of each of their committee members. Students would typically have at least one committee member from the Faculty of Education, which is synergetic, because these students would expect to take education courses to fulfill a degree in engineering education. However, students would also be required to take graduate level engineering courses from every engineering committee member's department, which could require taking more than one graduate level engineering course, thus making it problematic for students without an engineering degree.

One of the initial reasons for establishing the newly formed Centre for Engineering Professional Practice and Engineering Education in the Faculty of Engineering was to facilitate the Interdisciplinary Degree program. However, executing this plan encountered a major roadblock. Due to the structure of the Faculty of Graduate Studies at the University of Manitoba, CE2P2E is not considered a "unit" in the faculty of Graduate Studies. This means that any person who is a member of CE2P2E and supervises a graduate student must hold an adjunct appointment in an engineering department. In other words, their appointment in CE2P2E does not qualify them to supervise graduate students. Of principal importance here is that the academics with the most interest in engineering education are naturally appointed to CE2P2E; most of them do not hold adjunct status in an engineering department. The natural solution would be for interested academics to seek adjunct appointments in one of the four engineering departments within the Faculty; however, this adjunct appointment would then trigger the need for potential engineering education students to take a graduate level course in the particular engineering department as part of the Interdisciplinary Degree Program. 
The establishment of an Engineering Education Postgraduate Degree program will fulfill a long-standing aspiration to facilitate non-engineering students and academics (largely but not exclusively from Education) involvement in the Faculty of Engineering. But this is only the "functional" reason for the degree. The fundamental motivation for this initiative is that engineering education is an important and rapidly expanding area of scientific and creative scholarship and the University of Manitoba is committed to providing leadership in this area.

\section{PROGRAM DEVELOPMENT AT THE UNIVERSITY OF MANITOBA}

Early in 2015, two coordinators were appointed, one each from the Faculties of Education and Engineering, to recommend a course plan for the postgraduate degree program in engineering education to the Design Chair and the Dean of Education. Combining a literature review of existing globally located Engineering Education programs with other resources, the coordinators have amalgamated salient aspects of historical approaches on, and modern perspectives of, engineering education to create a new graduate program. The first iteration of the proposed program, which at this time is being conceived as a Master's degree, will be executed in five phases. It begins with a parallel, but independent dual-entry process. One entry stream is dedicated to students with an education background, while the other is for students entering with an engineering background. It is envisioned that these groups will begin the program as a unified cohort, enrolling in collective courses that provide a background in the historical and social context of engineering as well as an introduction to educational research methods: Phase 1. Following these introductory courses, each entry stream will dissociate to participate in specialized courses for their group for which they require expertise. Here, the Education entry students will engage in engineering-based courses focused on the design process (either alone or in combination with engineering graduate students who currently take the course), and the Engineering students will be introduced to an in-depth study of teaching and learning at the post-secondary level: Phase 2. Once this phase is complete, both entry streams will re-unite for collective courses on the views of teaching, paradigms and methodologies for carrying out inquiries into teaching as well as a more focused approach to research in engineering education: Phase 3. From here, Education entry students will have an opportunity to learn about Engineering Education in the $\mathrm{K}-12$ curriculum and how they can be prepared to instill an understanding and appreciation of the subject matter to students, while the Engineering entry students will engage in courses focused on pedagogical theory and practice, curriculum development, and innovative practices centered around Engineering Education at the post-secondary level: Phase 4. Once this phase is complete, both entry streams will embark on their capstone final project/thesis: Phase 5. Figure 1 shows the proposed curriculum. Courses with the designation EDUA, EDUB and ENG refer to those that already exist within the faculties. The courses without designations will need to be designed. This program plan has already been proposed to both the Faculties of Engineering and Education, and is currently under review.

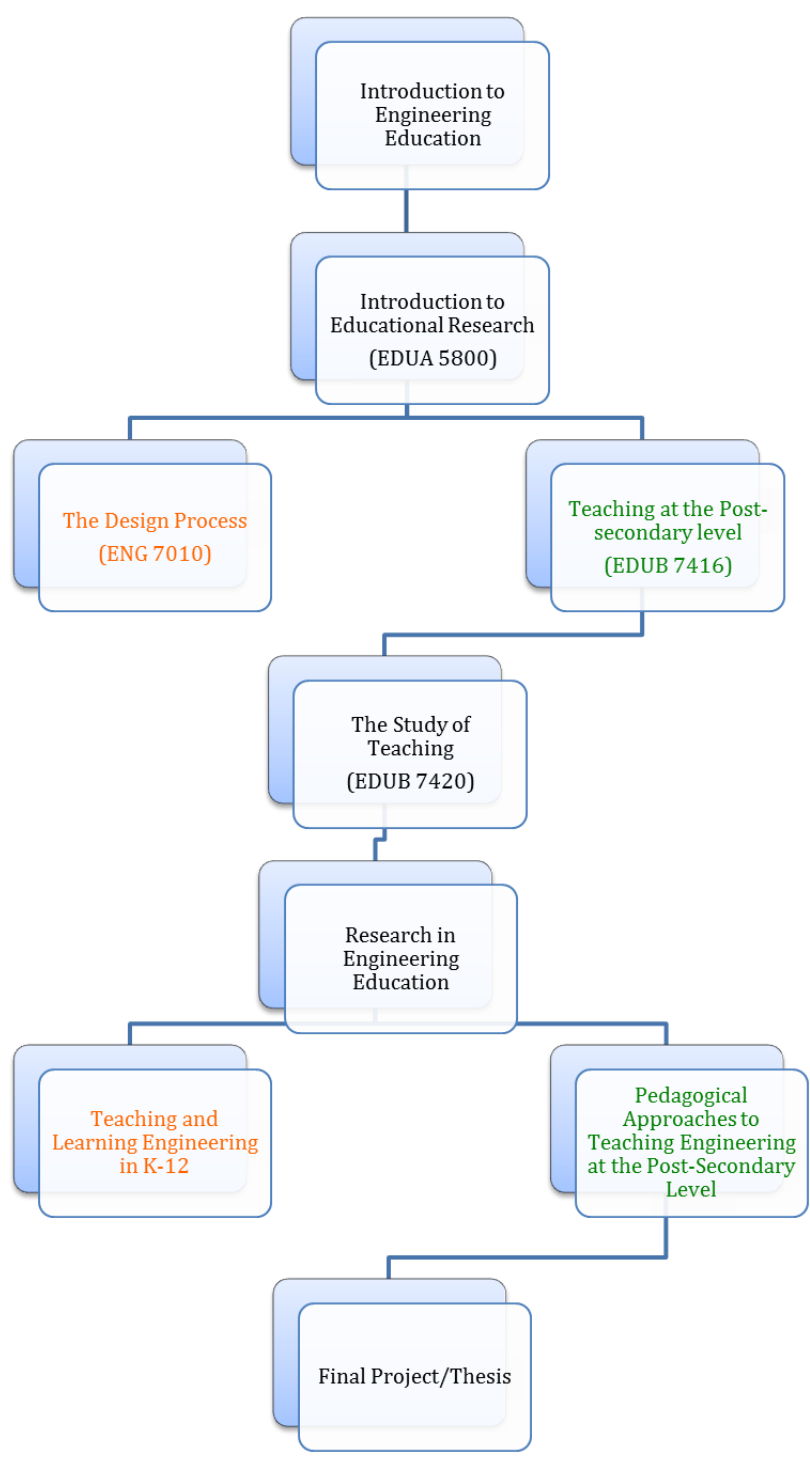

Fig. 1. Proposed curriculum for the Engineering Education Masters Degree Program at the University of Manitoba. 


\section{CONCLUSION}

While the engineering education landscape within universities continues to evolve, the University of Manitoba is breaking new ground with its proposed Engineering Education Graduate Program. Several developments within the last few years, including the formation of CEEA, changing $\mathrm{CEAB}$ accreditation requirements, and global influences have spurred a growing interest among Canadian engineering academics and practitioners in the field of engineering education. The University of Manitoba is poised to capitalize on these trends and develop a program of study that will benefit graduate students in the fields of both engineering and education to better understand and tackle the challenges that lie ahead. Increasingly, these two fields will no longer be seen as disparate from one another, but rather through their combined focus and scholarship on pedagogy, inextricably linked.

\section{Acknowledgements}

The authors wish to thank the University of Manitoba NSERC Design Chair, for support and funding of this initiative.

\section{References}

[1] Norman L. Fortenberry, "Foreword," in Cambridge Handbook of Engineering Education Research. New York, NY: Cambridge University Press, 2014, 763 pp.

[2] Aditya Johri and Barbara M. Olds, "Introduction," in Cambridge Handbook of Engineering Education Research. New York, NY: Cambridge University Press, 2014, 763 pp.

[3] Jeffrey E. Froyd and Jack Lohmann, "Chronological and ontological development of engineering education as a field of scientific inquiry," in Cambridge Handbook of Engineering Education Research. New York, NY: Cambridge University Press, 2014, 763 pp.

[4] Maura Borrego and Jonte Bernhard, "The emergence of engineering education research as an internationally connected field of inquiry," Journal of Engineering Education, vol. 100, no. 1, pp. 14-47, 2001.

[5] Brent Jesiek, Lynita, K. Newswander and Maura Borrego, "Engineering education research: Discipline, community or field?," Journal of Engineering Education, vol. 98, no. 1, pp. 39-52, 2009.

[6] Special Report, "The research agenda for the new discipline of engineering education," Journal of Engineering Education, vol. 95, no. 4, pp. 259-261, 2006.

[7] Barbara M. Olds, Barbara B. Moskal and Ronald L. Miller, "Assessment in engineering education: Evolution, approaches and future collaborations," Journal of Engineering Education, vol. 94, no. 1, pp. 13-25, 2005.

[8] Jennifer M. Case and Gregory Light, "Emerging methodologies in engineering education research, Journal of Engineering Education, vol. 100, no. 1, pp. 186-210, 2011.

[9] Wendy C. Newstetter and Marilla D. Svinicki, "Learning theories for engineering education practice," in Cambridge Handbook of Engineering Education Research. New York, NY: Cambridge University Press, 2014, 763 pp.

[10] Aditya Johri, Barbara M. Olds and Kevin O'Connor, "Situative frameworks for engineering learning research," in Cambridge Handbook of Engineering Education Research. New York, NY: Cambridge University Press, 2014, 763 pp.

[11] Wolff-Michael Roth, "The social nature of representational engineering knowledge," in Cambridge Handbook of Engineering Education Research, New York, NY: Cambridge University Press, 2014, 763 pp.

[12] Ruth A. Streveler, R. Shane Brown, Geoffrey L. Herman and Devlin Montfort, "Conceptual change and misconceptions in engineering education: Curriculum, measurement, and theory-focused approaches," in Cambridge Handbook of Engineering Education Research. New York, NY: Cambridge University Press, 2014, 763 pp.

[13] E.L. Boyer, Scholarship Reconsidered: Priorities of the Professoriate. San Francisco, CA: The Carnegie Foundation for the Advancement of Teaching, 1990, $147 \mathrm{pp}$. Available as of April 16, 2015 from http://www.umces.edu/sites/default/files/al/pdfs/BoyerScholars hipReconsidered.pdf

[14] David F. Radcliff, "Guest editorial: Shaping the discipline of engineering education," Journal of Engineering Education, vol. 95, no. 4, pp. 263-264, 2006.

[15] Diane T. Rover. Academic Bookshelf: Centered on Education Research. Journal of Engineering Education, vol. 94, no. 1, pp. 195-197, 2007.

[16] Michael J. Prince, Richard M. Felder and Rebecca Brent, "Does faculty research improve undergraduate teaching? An analysis of existing and potential synergies,' Journal of Engineering Education, vol. 96, no. 4, pp. 283-294., 2007.

[17] Gary Lichtenstein, Helen L. Chen, Karl H. Smith, and Theresa Maldonado, "Retention and persistence of women and minorities along the engineering pathway in the United States, in Cambridge Handbook of Engineering Education Research. Cambridge University Press, 2014, 763 pp.

[18] Karl A. Smith, Sheri D. Sheppard, David W. Johnson and Roger T. Johnson, "Pedagogies of engagement: Classroom-based practices," Journal of Engineering Education, vol. 94, no. 1, pp.87-101, 2005.

[19] Ruth Streveler, Barbara M. Moskal, Ronald Miller, and Michael Pavelich, "Center for engineering education: Colorado 
School of Mines," Journal of Engineering Education, vol. 90, no. 3, pp.383-387, 2001.

[20] Phillip C. Wankat, "Analysis of the first ten years of the Journal of Engineering Education," Journal of Engineering Education, vol. 93, no. 7, pp.13-21, 2004.

[21] Engineering Education Research and Teaching Centers. Available as of May 01, 2015, from the Engineering Education Community Resource wiki: http://engineeringeducationlist.pbworks.com/w/page/27610370/ Engineering\%20Education\%20Research\%20and\%20Teaching \%20Centers

[22] Lisa C. Benson, Kurt Becker, Melanie M. Cooper, O. Hayden Griffin and Karl A. Smith, "Engineering education: Departments, degrees and directions," International Journal of Engineering Education, vol. 26, no. 5, pp. 1042-1048, 2010.

[23] Aditya Johri and Brent Jesiek, "Global and international issues in engineering education," in Cambridge Handbook of Engineering Education Research. New York, NY: Cambridge University Press, 2014, 763 pp.

[24] "Collaborative Program in Engineering Education (EngEd)," University of Toronto, Faculty of Applied Science and Engineering, Engineering Graduate Studies. Available as of May $1, \quad 2015 \quad$ from http://gradstudies.engineering.utoronto.ca/researchdegrees/collaborative-program-engineering-education/

[25] Brian Frank, Susan McCahan, K. Christopher Watts, Susan Fostaty Young, Peter Ostafichuck, Peter Wolf and Nasser Saleh, "Engineering graduate attribute development (EGAD) project," in Proc. CEAA Canadian Engineering Conf., CEEC11, Andy Fisher (ed.) (St. John's, NL; 6-8 June 2011), pp. 3, 2011 .

[26] Peter Wolf and Warren Stiver, "Graduate attributes: Intentional mapping and assessment portfolios," in Proc. CEAA Canadian Engineering Conf., CEEC11, Andy Fisher (ed.) (St. John's, NL; 6-8 June 2011), pp. 4, 2011.

[27] Brian Frank and Susan Fostaty Young, "What can our students do: Year 2 of graduate attribute assessment at Queen's University," in Proc. CEAA Canadian Engineering Conf., CEEC11, Andy Fisher (ed.) (St. John's, NL; 6-8 June 2011), pp. 6, 2011.

[28] Eli Fromm, "Inaugural Bernard M. Gordon Lecture: The changing engineering education paradigm," Journal of Engineering Education, vol. 92, no. 2, pp. 113-121, 2003.

[29] L. Dee Fink, Susan Ambrose and Daniel Wheeler, "Becoming a professional engineering educator: A new role for a new era," Journal of Engineering Education, vol. 94, no. 1, pp. 185-187, 2005.

[30] Maura Borrego, "Development of engineering education as a rigorous discipline: A study of the publication patterns of four coalitions," Journal of Engineering Education, vol. 96, no. 1, pp. 5-18, 2007.
[31] Ruth Streveler, Barbara Moskal and Ronald Miller, "Using Boyer's Four Forms of Scholarship to Advance Engineering Education," Journal of Scholarship of Teaching and Learning, vol. 3, no. 2, 2003.

[32] Brian Frank, "DuPont Chair of Engineering Education and Development," Faculty of Engineering and Applied Science, Queen's University. Available as of May 1, 2015 from http://engineering.queensu.ca/Integrated-Learning-

Center/Integrated-Learning-at-Queens/EngineeringEducation.html

[33] "Engineering Education," Schulich School of Engineering, University of Calgary. Available as of May 1, 2015 from http://schulich.ucalgary.ca/keywords/engineeringeducation

\section{APPENDIX A: ENGINEERING EDUCATION DEPARTMENTS \& PROGRAMS (GRADUATE) [21]}

\begin{tabular}{|c|c|c|c|}
\hline \multicolumn{4}{|c|}{ Engineering/STEM Education Graduate Programs } \\
\hline Institution & Country & Program & $\begin{array}{l}\text { Degrees } \\
\text { Awarded }\end{array}$ \\
\hline Aalborg University & Denmark & $\begin{array}{l}\text { UNESCO Chair in } \\
\text { Problem Based } \\
\text { Learning in } \\
\text { Engineering }\end{array}$ & $\begin{array}{l}\text { Ph.D. in } \\
\text { Engineering } \\
\text { Education (joint } \\
\text { with UTM } \\
\text { (Malaysia)) } \\
\text { Ph.D. in PBL in } \\
\text { Engineering } \\
\text { Education } \\
\text { Master in PBL in } \\
\text { Engineering and } \\
\text { Science }\end{array}$ \\
\hline $\begin{array}{l}\text { Arizona State } \\
\text { University }\end{array}$ & USA & $\begin{array}{l}\text { Mary Lou Fulton } \\
\text { Teachers College }\end{array}$ & $\begin{array}{l}\text { Ph.D. and M.Ed. in } \\
\text { Educational } \\
\text { Technology } \\
\text { Ph.D. in Learning, } \\
\text { Literacies and } \\
\text { Technologies } \\
\text { Ph.D. in } \\
\text { Curriculum and } \\
\text { Instruction with } \\
\text { concentration in } \\
\text { Engineering } \\
\text { Education (more } \\
\text { info) }\end{array}$ \\
\hline & & $\begin{array}{l}\text { Ira A. Fulton } \\
\text { School of } \\
\text { Engineering }\end{array}$ & $\begin{array}{l}\text { Ph.D. Engineering } \\
\text { Education } \\
\text { Systems and } \\
\text { Design (coming } \\
\text { soon) } \\
\text { Ph.D. Aerospace } \\
\text { Engineering with } \\
\text { concentration in } \\
\text { Engineering } \\
\text { Education } \\
\text { Ph.D. Mechanical } \\
\text { Engineering with } \\
\text { concentration in } \\
\text { Engineering } \\
\text { Education }\end{array}$ \\
\hline $\begin{array}{l}\text { University of } \\
\text { California - } \\
\text { Berkeley }\end{array}$ & USA & $\begin{array}{l}\text { Graduate School } \\
\text { of Education }\end{array}$ & $\begin{array}{l}\text { Ph.D. in Studies in } \\
\text { Engineering, } \\
\text { Science, and } \\
\text { Mathematics } \\
\text { (SESAME) } \\
\text { Education }\end{array}$ \\
\hline $\begin{array}{l}\text { Chalmers } \\
\text { University of } \\
\text { Technology }\end{array}$ & Sweden & $\begin{array}{l}\text { Department of } \\
\text { Applied } \\
\text { Information } \\
\text { Technology }\end{array}$ & $\begin{array}{l}\text { Ph.D. Engineering } \\
\text { Education } \\
\text { Research }\end{array}$ \\
\hline $\begin{array}{l}\text { University of } \\
\text { Cincinnati }\end{array}$ & USA & $\begin{array}{l}\text { School of } \\
\text { Engineering } \\
\text { Education (SEE) }\end{array}$ & \\
\hline Clemson University & USA & $\begin{array}{l}\text { Department of } \\
\text { Engineering and }\end{array}$ & $\begin{array}{l}\text { Ph.D. Engineering } \\
\text { or Science }\end{array}$ \\
\hline
\end{tabular}




\begin{tabular}{|c|c|c|c|}
\hline & & Science Education & Education \\
\hline $\begin{array}{l}\text { Universiti } \\
\text { Kebangsaan } \\
\text { Malaysia }\end{array}$ & Malaysia & $\begin{array}{l}\text { Centre for } \\
\text { Engineering } \\
\text { Education } \\
\text { Research (CEER) }\end{array}$ & $\begin{array}{l}\text { Ph.D. Engineering } \\
\text { Education }\end{array}$ \\
\hline $\begin{array}{l}\text { University of } \\
\text { Kentucky }\end{array}$ & USA & $\begin{array}{l}\text { College of } \\
\text { Education - } \\
\text { Department of } \\
\text { STEM Education }\end{array}$ & $\begin{array}{l}\text { Ph.D. in Education } \\
\text { Sciences }\end{array}$ \\
\hline $\begin{array}{l}\text { Linköping } \\
\text { University }\end{array}$ & Sweden & $\begin{array}{l}\text { Department of } \\
\text { Science \& } \\
\text { Technology - } \\
\text { Division of Physics } \\
\text { and Electronics }\end{array}$ & $\begin{array}{l}\text { Engineering } \\
\text { Education } \\
\text { Engineering } \\
\text { Education } \\
\text { Research Group }\end{array}$ \\
\hline $\begin{array}{l}\text { Louisiana Tech } \\
\text { University }\end{array}$ & USA & $\begin{array}{l}\text { College of } \\
\text { Engineering and } \\
\text { Science }\end{array}$ & $\begin{array}{l}\text { Ph.D. in } \\
\text { Engineering with } \\
\text { Engineering } \\
\text { Education } \\
\text { concentration }\end{array}$ \\
\hline $\begin{array}{l}\text { University of } \\
\text { Maryland }\end{array}$ & USA & $\begin{array}{l}\text { College of } \\
\text { Education }\end{array}$ & $\begin{array}{l}\text { Ph.D. in STEM } \\
\text { Education }\end{array}$ \\
\hline $\begin{array}{l}\text { The College of } \\
\text { New Jersey }\end{array}$ & USA & $\begin{array}{l}\text { School of } \\
\text { Engineering - } \\
\text { Department of } \\
\text { Technological } \\
\text { Studies }\end{array}$ & $\begin{array}{l}\text { M.A.T. in } \\
\text { Secondary } \\
\text { Education - } \\
\text { Technology } \\
\text { Education }\end{array}$ \\
\hline Niagara University & USA & $\begin{array}{l}\text { College of } \\
\text { Education }\end{array}$ & $\begin{array}{l}\text { M.S. Ed. Math, } \\
\text { Science, and } \\
\text { Technology } \\
\text { Education }\end{array}$ \\
\hline $\begin{array}{l}\text { North Carolina } \\
\text { State University }\end{array}$ & USA & $\begin{array}{l}\text { College of } \\
\text { Education - } \\
\text { Department of } \\
\text { Science, } \\
\text { Technology, } \\
\text { Engineering, and } \\
\text { Mathematics } \\
\text { Education }\end{array}$ & $\begin{array}{l}\text { M.S. and M.Ed. } \\
\text { Program in } \\
\text { Technology } \\
\text { Education } \\
\text { Ed.D. Program in } \\
\text { Technology } \\
\text { Education }\end{array}$ \\
\hline $\begin{array}{l}\text { Old Dominion } \\
\text { University }\end{array}$ & USA & $\begin{array}{l}\text { Darden College of } \\
\text { Education - } \\
\text { Department of } \\
\text { STEM Education } \\
\text { \& Professional } \\
\text { Studies }\end{array}$ & $\begin{array}{l}\text { Ph.D. } \\
\text { Concentration in } \\
\text { Occupational and } \\
\text { Technical Studies }\end{array}$ \\
\hline $\begin{array}{l}\text { The Ohio State } \\
\text { University }\end{array}$ & USA & $\begin{array}{l}\text { Science, } \\
\text { Technology, } \\
\text { Engineering, \& } \\
\text { Mathematics } \\
\text { Education }\end{array}$ & $\begin{array}{l}\text { Ph.D. Technology } \\
\text { \& Engineering } \\
\text { Education }\end{array}$ \\
\hline Purdue University & USA & $\begin{array}{l}\text { School of } \\
\text { Engineering } \\
\text { Education }\end{array}$ & $\begin{array}{l}\text { Ph.D. Engineering } \\
\text { Education }\end{array}$ \\
\hline $\begin{array}{l}\text { University of Texas } \\
\text { at Austin }\end{array}$ & USA & $\begin{array}{l}\text { College of } \\
\text { Education }\end{array}$ & $\begin{array}{l}\text { Ph.D. STEM } \\
\text { Education } \\
\text { M.A. or M.Ed. } \\
\text { STEM Education }\end{array}$ \\
\hline Tufts University & USA & $\begin{array}{l}\text { Department of } \\
\text { Education }\end{array}$ & $\begin{array}{l}\text { M.S. Science, } \\
\text { Technology, } \\
\text { Engineering } \\
\text { Education or Math } \\
\text { (STEM) } \\
\text { Ph.D Science, } \\
\text { Technology, } \\
\text { Engineering } \\
\text { Education, or Math } \\
\text { (STEM) } \\
\text { Master of Arts in } \\
\text { Teaching - } \\
\text { Engineering } \\
\text { Masters of Arts in } \\
\text { Teaching - } \\
\text { Elementary STEM } \\
\text { Education }\end{array}$ \\
\hline $\begin{array}{l}\text { Universidad de las } \\
\text { Americas, Puebla }\end{array}$ & Mexico & $\begin{array}{l}\text { EDEI - The School } \\
\text { of Engineering }\end{array}$ & $\begin{array}{l}\text { Ph.D. in Education } \\
\text { of Sciences, } \\
\text { Engineering and } \\
\text { Technologies }\end{array}$ \\
\hline $\begin{array}{l}\text { Universiti } \\
\text { Teknologi Malaysia }\end{array}$ & Malaysia & $\begin{array}{l}\text { Department of } \\
\text { Technical and } \\
\text { Engineering } \\
\text { Education } \\
\text { Training and } \\
\text { Research in } \\
\text { Engineering } \\
\text { Education (TREE) }\end{array}$ & $\begin{array}{l}\text { Ph.D. in } \\
\text { Engineering } \\
\text { Education } \\
\text { Ph.D. in } \\
\text { Engineering } \\
\text { Education (joint } \\
\text { with AAU } \\
\text { (Denmark)) }\end{array}$ \\
\hline Uppsala University & Sweden & $\begin{array}{l}\text { Uppsala } \\
\text { Computing } \\
\text { Education } \\
\text { Research Group } \\
\text { (UpCERG) }\end{array}$ & $\begin{array}{l}\text { Ph.D. in Computer } \\
\text { Science with } \\
\text { specialization in } \\
\text { Computer Science } \\
\text { Education } \\
\text { Research }\end{array}$ \\
\hline Utah State & USA & Department of & M.S. Engineering \\
\hline
\end{tabular}

\begin{tabular}{|l|l|l|l|}
\hline University & Engineering & $\begin{array}{l}\text { and Technology } \\
\text { Education, } \\
\text { Ph.D. Engineering } \\
\text { Education }\end{array}$ \\
\hline
\end{tabular}

\section{APPENDIX B: ENGINEERING EDUCATION- RELATED CERTIFICATE PROGRAMS [21]}

\begin{tabular}{|c|c|c|c|}
\hline \multicolumn{4}{|c|}{ Engineering Education-Related Certificate Programs } \\
\hline Institution & Country & $\begin{array}{l}\text { School, } \\
\text { College, } \\
\text { Department }\end{array}$ & $\begin{array}{l}\text { Certificate } \\
\text { Awarded }\end{array}$ \\
\hline $\begin{array}{l}\text { Arizona State } \\
\text { University }\end{array}$ & USA & $\begin{array}{l}\text { Mary Lou Fulton } \\
\text { Teachers College }\end{array}$ & $\begin{array}{l}\text { Educational } \\
\text { Technology } \\
\text { Certificate } \\
\text { Technology for } \\
\text { Teaching and } \\
\text { Learning } \\
\text { Certificate }\end{array}$ \\
\hline $\begin{array}{l}\text { Boise State } \\
\text { University }\end{array}$ & USA & $\begin{array}{l}\text { College of } \\
\text { Engineering }\end{array}$ & $\begin{array}{l}\text { Certificate in } \\
\text { Secondary } \\
\text { Teaching for } \\
\text { Engineers }\end{array}$ \\
\hline $\begin{array}{l}\text { Clemson } \\
\text { University }\end{array}$ & USA & $\begin{array}{l}\text { Department of } \\
\text { Engineering and } \\
\text { Science Education }\end{array}$ & $\begin{array}{l}\text { Certificate in } \\
\text { Engineering and } \\
\text { Science Education }\end{array}$ \\
\hline $\begin{array}{l}\text { Michigan State } \\
\text { University }\end{array}$ & USA & $\begin{array}{l}\text { College of } \\
\text { Engineering }\end{array}$ & $\begin{array}{l}\text { College Teaching } \\
\text { Certificate }\end{array}$ \\
\hline $\begin{array}{l}\text { University of } \\
\text { Michigan }\end{array}$ & USA & $\begin{array}{l}\text { Center for } \\
\text { Research on } \\
\text { Learning and } \\
\text { Teaching (CRLT) }\end{array}$ & $\begin{array}{l}\text { Certificate in } \\
\text { Engineering } \\
\text { Education } \\
\text { Research }\end{array}$ \\
\hline $\begin{array}{l}\text { North Dakota State } \\
\text { University }\end{array}$ & USA & $\begin{array}{l}\text { Center for Science } \\
\text { \& Mathematics } \\
\text { Education (CSME) }\end{array}$ & $\begin{array}{l}\text { Graduate } \\
\text { Certificate } \\
\text { Program in College } \\
\text { Teaching }\end{array}$ \\
\hline $\begin{array}{l}\text { University of St. } \\
\text { Thomas }\end{array}$ & USA & $\begin{array}{l}\text { Center for } \\
\text { Engineering } \\
\text { Education }\end{array}$ & $\begin{array}{l}\text { Graduate } \\
\text { Certificate in } \\
\text { Engineering } \\
\text { Education }\end{array}$ \\
\hline Virginia Tech & USA & $\begin{array}{l}\text { Department of } \\
\text { Engineering } \\
\text { Education }\end{array}$ & $\begin{array}{l}\text { Engineering } \\
\text { Education } \\
\text { Graduate } \\
\text { Certificate }\end{array}$ \\
\hline & & $\begin{array}{l}\text { School of } \\
\text { Education }\end{array}$ & $\begin{array}{l}\text { Integrative STEM } \\
\text { Education } \\
\text { Graduate } \\
\text { Certificate } \\
\text { Program } \\
\end{array}$ \\
\hline
\end{tabular}

\section{APPENDIX C: INNOVATIVE ENGINEERING AND INTER/CROSS-DISCIPLINARY \\ PROGRAMS [21]} Innovative Engineering and Inter/Cross-Disciplinary Programs

\begin{tabular}{|c|c|c|c|}
\hline Institution & Country & Program & \\
\hline Aalborg University & Denmark & $\begin{array}{l}\text { Department of } \\
\text { Development and } \\
\text { Planning }\end{array}$ & $\begin{array}{l}\text { M.S. Problem } \\
\text { Based Learning in } \\
\text { Engineering and } \\
\text { Science }\end{array}$ \\
\hline $\begin{array}{l}\text { Carnegie Mellon } \\
\text { University }\end{array}$ & USA & $\begin{array}{l}\text { Program in } \\
\text { Interdisciplinary } \\
\text { Educational } \\
\text { Research (PIER) }\end{array}$ & $\begin{array}{l}\text { Ph.D. in } \\
\text { Interdisciplinary } \\
\text { Educational } \\
\text { Research via } \\
\text { Mechanical } \\
\text { Engineering } \\
\text { program }\end{array}$ \\
\hline $\begin{array}{l}\text { King Abdullah } \\
\text { University of } \\
\text { Science and } \\
\text { Technology } \\
\text { (KAUST) }\end{array}$ & Saudi Arabia & & Ph.D. Program \\
\hline $\begin{array}{l}\text { National Institutes } \\
\text { of Technical } \\
\text { Teachers' Training } \\
\text { \& Research }\end{array}$ & India & & $\begin{array}{l}\text { Ph.D. Programme } \\
\text { in Engineering } \\
\text { Education (Inter- } \\
\text { disciplinary } \\
\text { Research) } \\
\text { Master of } \\
\text { Technology Human } \\
\text { Resource } \\
\text { Development } \\
\text { Master of Technical } \\
\text { Education }\end{array}$ \\
\hline
\end{tabular}

CEEA15; Paper 039 
Proc. 2015 Canadian Engineering Education Association (CEEA15) Conf.

\begin{tabular}{|c|c|c|c|}
\hline $\begin{array}{l}\text { North Dakota } \\
\text { State University }\end{array}$ & USA & $\begin{array}{l}\text { College of } \\
\text { Engineering \& } \\
\text { Architecture, } \\
\text { College of } \\
\text { Mathematics \& } \\
\text { Sciences, and } \\
\text { College of Human } \\
\text { Development \& } \\
\text { Education }\end{array}$ & $\begin{array}{l}\text { Ph.D. in STEM } \\
\text { Education }\end{array}$ \\
\hline $\begin{array}{l}\text { Stony Brook } \\
\text { University }\end{array}$ & USA & $\begin{array}{l}\text { Department of } \\
\text { Technology and } \\
\text { Society }\end{array}$ & $\begin{array}{l}\text { Ph.D. in } \\
\text { Technology, Policy, } \\
\text { and Innovation } \\
\text { (TPI) }\end{array}$ \\
\hline $\begin{array}{l}\text { Texas A\&M } \\
\text { University }\end{array}$ & USA & $\begin{array}{l}\text { College of } \\
\text { Engineering }\end{array}$ & $\begin{array}{l}\text { Ph.D in } \\
\text { Interdisciplinary } \\
\text { Engineering }\end{array}$ \\
\hline $\begin{array}{l}\text { University of } \\
\text { Georgia }\end{array}$ & USA & $\begin{array}{l}\text { Faculty of } \\
\text { Engineering } \\
\text { (more information } \\
\text { at:: Engineering } \\
\text { Education } \\
\text { Research } \\
\text { CLUSTER) }\end{array}$ & $\begin{array}{l}\text { M.S. and PhD in } \\
\text { Engineering with } \\
\text { Area of Emphasis } \\
\text { in Engineering } \\
\text { Education } \\
\text { Research }\end{array}$ \\
\hline $\begin{array}{l}\text { University of } \\
\text { Washington }\end{array}$ & USA & $\begin{array}{l}\text { Human Centered } \\
\text { Design \& } \\
\text { Engineering }\end{array}$ & $\begin{array}{l}\text { Ph.D. in Human } \\
\text { Centered Design \& } \\
\text { Engineering } \\
\text { (HCDE) }\end{array}$ \\
\hline $\begin{array}{l}\text { University of } \\
\text { Florida }\end{array}$ & USA & $\begin{array}{l}\text { College of } \\
\text { Engineering }\end{array}$ & $\begin{array}{l}\text { Ph.D in Materials } \\
\text { Science and } \\
\text { Engineering with } \\
\text { research emphasis } \\
\text { in } \\
\text { Engineering } \\
\text { Education }\end{array}$ \\
\hline
\end{tabular}

CEEA15; Paper 039

McMaster University; May 31 - June 3, 2015

-8 of $8-$ 